\title{
LA EXPULSIÓN DEL MERCADER JUAN PÉREZ, UN MORISCO DE TOLEDO
}

\author{
Anthony M. Puglisi*
}

En enero de 1610, el morisco granadino Juan Pérez, vecino de Toledo, se marchó para Francia. Según su testimonio respondía al "permiso" que Felipe III (1598) les "concedió" a los moriscos de las dos Castillas, La Mancha y Extremadura después de la expulsión de los musulmanes valencianos ${ }^{1}$. Sin duda a su pesar, fue detenido en Durango, Vizcaya, una desgracia que desencadenó un proceso judicial complicado por su diversidad de instancias, entre ellas de la Real Chancillería de Valladolid. Lo que complicó el proceso fue la avaricia de los oficiales que lo arrestaron: se enteraron de que Pérez llevaba 20.600 reales y otros bienes. De denuncia en denuncia (porque Pérez se defendió apelando las sentencias de Durango) el fiscal del rey y el conde de Salazar se involucraron en el caso. La magnitud de los legajos, además de su condición desordenada, requiere y justifica una detallada explicación cronológica de los sucesos, lo que pretendemos aquí en el presente artículo. El conjunto de pleitos revela la vulnerabilidad de los moriscos expelidos a las autoridades judiciales al mismo tiempo que expone la corrupción que podían ejemplificar estos oficiales.

De hecho, esta aportación documental añade a lo poco que se sabe de la corrupción de las justicias que trataron de aprovecharse de los moriscos que viajaron al exilio. La práctica quizá fuese común². En teoría los moriscos no debían atraer tal atención porque las pragmáticas de expulsión prohibieron que los moriscos sacasen dinero y joyas del país. Así pues, los intentos de aprovecharse de ellos económicamente reflejan un pesimismo con respeto a la esperanza de que se obedeciesen las normas. El edicto particular al que Pérez dijo que respondía se publicó el 2 de enero de 1610, poco después de la expulsión de los moriscos valencianos. Este nuevo decreto real para las dos Castillas, La Mancha y Extremadura comunicó una "licencia bondadosa" del rey:

\footnotetext{
* Slippery Rock University of Pennsylvania.

1. Expreso mi profundo agradecimiento a Mercedes García-Arenal por sus sugerencias, comentarios y consejos con respecto a este estudio.

2. M.E. Perry, The Handless Maiden, Princeton, Nueva Jersey, 2005, pp. 152-155.
} 
"[Yo, el Rey] mandé que saliesen desde Valencia todos los Christianos nuevos Moriscos, que estauan, y residian en el, y que se fuesen fuera destos dichos Reynos de España, por las causas que se declaran en el vando que sobre ello mandé publicara en el dicho Reyno, y ahora viendo, que los de la dicha nación que habitan en los Reynos de Castilla Vieja, Nueva, Estremadura, y la Mancha, se han inquietado, y dado ocasión de pensar que tienen gana de yrse a viuir fuera destos dichos Reynos ... permito y doy licencia, en virtud de la presente, a todos los que se quisieran yr destos mis Reynos y Señorios de España viuir fuera dellos, adonde bien visto les fuere... y tengo por bien, que puedan durante el dicho tiempo disponer de sus bienes, muebles, y semouientes, y no de los rayzes, y lleuarlos, no en moneda, oro, plata, ni joyas ni letras de cambio, sino en mercadurías..."

Más adelante nos fijaremos en la última frase de nuestra cita al bando en que se prohibía que los moriscos se llevasen dinero fuera de España, la cuestión central de las instancias y procesos de Pérez. Por ahora observamos que aunque el texto hace parecer que no se programaba la expulsión de todos los moriscos de España en el momento en que Felipe III firmó el edicto, los papeles secretos del consejo de Estado del rey confirman que en 1609 se veía la expulsión de Valencia como la primera etapa de un plan para todos los reinos de España ${ }^{4}$. Tampoco representa la actitud del rey y sus consejeros: Felipe III mismo había dicho en 1609 que todos los moriscos "se pueden justamente pasar a cuchillo"

Esta opinión sobre los cristianos nuevos fue inspirada por la rebelión de las Alpujarras del Reino de Granada (1568-1572) ${ }^{6}$. El levantamiento de los moriscos granadinos demostró que no querían vivir sin su idioma árabe y sus costumbres, que fueron prohibidas. También esa guerra reveló que los moriscos tenían contactos con Berbería y otras partes del extranjero musulmán: los rebeldes habían procurado la ayuda de los argelinos y les pidieron socorro a los turcos. La confirmación de su habilidad y voluntad de solicitar alianzas de otros países tal vez llamase tanta atención que la Corona se cercioró de la existencia de espionaje morisco después de la rebelión granadina, los esfuerzos por parte de unos cristianos nuevos de buscar contactos con la protestante nación inglesa. Adicionalmente, se confirmó que algunos individuos viajaban a Francia y al Norte de África cuando se prohibía estas salidas del país ${ }^{7}$. En el Magreb eran conocidos como andalusíes, y sus viajes al África pueden fecharse desde el siglo XII,

3. Archivo de la Real Chancillería de Valladolid (ARCV), c. 4470-3, ff. 3-5. También se encuentra una transcripción completa del mismo edicto en P. BORONAT Y BARRACHINA, Los moriscos españoles y su expulsión, Valencia, 2, 1901, p. 288.

4. Archivo General de Simancas (AGS), Estado, leg. 2638 Bis., f. 3r.

5. Ibídem, f. $17 \mathrm{r}$.

6. J. CAro Baroja, Los moriscos del reino de Granada, Madrid, 1976, p. 197; B. Vincent y A. DoMíNGUEZ ORTIZ, Los moriscos: Vida y tragedia de una minoría, Madrid, 1978, p. 57.

7. L.P. Harvey, Muslims in Spain: 1500 to 1614, Chicago, 2005, pp. 342-347. 
lo cual confirma que sus principales intereses fueron mercantiles ${ }^{8}$. Sin embargo, el descubrimiento de que los moriscos salían de España llegó a definir al morisco como "traidor" por sus contactos con el norte de África'. Por eso es probable que las autoridades de Vizcaya detuviesen a Pérez fijándose en la cercanía de la frontera con Francia y fuese costumbre vigilar los caminos.

El concepto del morisco como traidor seglar y religioso podría haber justificado la expulsión suficientemente. Es difícil, sin embargo, medir la actitud popular hacia los moriscos en el momento en que se decidió su destierro, un punto de vista que no se relacionaba con el trabajo policial, clérigo ni militar pero que sin duda influenciaba la perspectiva de los miembros de estos sectores. Posiblemente algunos españoles se conmocionasen con ellos mientras otros opinasen que sufrieron un castigo merecido. Una hoja suelta de las que se repartían en las ciudades grandes demuestra que la población cristiana no simpatizaba con los moriscos desterrados como nuestro Juan Pérez. Este romance callejero, pretendiendo ser gracioso, no mostraba ninguna misericordia:

"Que por traydores, y Herejes,

dos bien legitimas causas

para confiscar sus bienes,

y conuertillos en brasas.

A España desocupeys,

porque como gente ingrata

después de ochocientos años

quisistes, darle la paga.

Ya que por premio os obliga,

a que llebéis empleada

la semouiente hazienda,

pues os dexa de gracia"10.

Parece probable que el autor de este poema observase a los expulsados andando hacia el extranjero, cargados de todos sus bienes. Para esta voz poética la expulsión es justa porque, según sus versos, los moriscos son "traidores" y además "herejes". Los "consejos" a los que se refiere el título del romance enumeran todo lo que los expelidos podían vender en Francia y Berbería.

La existencia de este documento popular, además de indicar que había un mercado antimorisco dispuesto a comprar poemas que se burlaban de la desgracia de los desterrados, señala una conciencia popular de los reales decretos de la expulsión. Volvamos al asunto de las monedas y las mercadurías: los mo-

8. M. de EpalzA, «Estructuras de acogida de los moriscos emigrantes de España en el Mágreb (Siglos XIII al XVIII)», Alternativas: Cuadernos de Trabajo Social, 4, 1996, pp. 35-48.

9. A. Chejne, Islam and the West: The Moriscos, Albany, Nueva York, 1983, 8.

10. «Romance de los consejos, que dio un soldado a los Moriscos, cerca de emplear sus dineros, para aprovecharse», en I. BAUER LANDAUER, Papeles de mi archivo. Relaciones y manuscritos (moriscos), Madrid, 1923, p. 182. 
riscos, si querían irse, tenían que cambiar su dinero y joyas por materiales vendibles, tratar de viajar escondiéndolos o abandonarlos. El romance popular que hemos citado alude claramente a la prohibición de que sacasen dinero de España. Comentaba, entonces, al mismo tiempo que anunciaba un hecho: podía haber moriscos con objetos de valor en el camino. Semejantes expresiones populares en forma poética despertaron la ya antigua superstición de "quien tiene moro tiene oro".

El aviso no sólo se basaba en estereotipos sobre el morisco que ocultaba bienes (fuesen mercadurías o monedas), sino en experiencias previas: España ya había visto la expulsión de los moriscos del Reino de Granada. En 1572, varios moriscos granadinos enterraron sus bienes antes de someterse a la expulsión general al final de la guerra de las Alpujarras, planeando volver algún día a reclamarlos ${ }^{11}$. El caso de Juan Pérez, como veremos, es un producto de estas manifestaciones y creencias populares porque la raíz de la interrupción de su viaje fue la codicia de lo que llevaba oculto. Las justicias corruptas que lo arrestaron y le robaron su dinero en Durango habrían conocido lo que poemas como el «Romance de los consejos» comunicaban. Además, otros estereotipos que se usaban para describir a los moriscos - de que olían mal, eran tacaños y codiciosos, que siempre mentían- eran fruto de la gran denuncia de que fuesen traidores y socavasen el bienestar español ${ }^{12}$. Pérez recibió el trato que las autoridades de Vizcaya le dieron no sólo porque sabían que era posible que tuviese objetos de valor sino también porque les parecía que era su derecho tratar a un morisco de esa manera por ser étnicamente inferior.

Aunque era consciente de su marginalidad y de la existencia de malintencionados, Pérez no podía prever que iba a ser acosado por una autoridad policial cuando partió de Toledo. Llegó a la Merindad de Durango, Vizcaya, el 24 de enero de 1610 y tal vez porque parecía que no venía cargado despertase las sospechas de las justicias. Al día siguiente, Martín de Sagasta, el teniente de prestamero de la merindad, se tropezó con él y un arriero morisco que se llamaba Francisco Fernández. Pérez y Fernández se fugaron de la escena del encuentro. Sagasta enseguida acudió a Martín de Zaldívar, el lugarteniente de la justicia de Durango, denunciando a Pérez y su compañero: "que parecen moriscos cuyos nombres y lo demás provisto verificar en la prosecución de esta causa", suponiendo que ambos individuos buscaban la frontera con Francia, y "andan por mayor secreto y disimulación con sus armas como cristianos viejos y fuera de sus alojamientos y de ellos y del dinero, joyas y cabalgaduras que lle-

11. M. BARrios Aguilera, La suerte de los vencidos: Estudios y reflexiones sobre la cuestión morisca, Granada, 2009, pp. 267-270.

12. J.M. PerCEVAL, «Asco y asquerosidad del morisco según los apologistas cristianos del Siglo de Oro», La Torre, 13, 1986, pp. 21-47, 43; Id., «Las relaciones entre cristianos y moriscos: La construcción del 'otro' que fue expulsado en 1609», en A. MOLINER PRADA, La expulsión de los moriscos, Barcelona, 2009, pp. 41-64. 
van sin licencia de su majestad y sin guardar las leyes y pragmáticas, órdenes y bandos de su majestad"13.

Sagasta no explicó por qué creía que eran moriscos pero evidentemente su apariencia física, modo de vestirse y la profesión de arriero de Fernández eran suficientes para que estuviese convencido de esa identidad de los forasteros. Un foráneo encontrado en una localidad vizcaína probablemente llamase la atención, y más si parecía un cristiano nuevo: la ley de Vizcaya no era generosa con los que venían desde fuera del condado. En su Ley XIII, el Fuero nuevo de Vizcaya prohibía que los descendientes de moros y judíos morasen ahí y dictaba que todos los "extranjeros" que quisiesen establecerse como pobladores de Vizcaya tenían que someterse a un examen de linaje para asegurar que no eran descendientes de judíos ni moros ${ }^{14}$. Nos interesa que Sagasta se enfocase tanto en el "mayor secreto y disimulación" en su denuncia. Para él, y más adelante para Zaldívar también, lo más importante era lo que podía estar escondiendo el morisco.

El mismo día de su acusación formal, Sagasta volvió a Zaldívar llevando a los dos moriscos presos. El lugarteniente luego comenzó el interrogatorio. En los exámenes repetidos de Zaldívar se encuentran las ganas de aprovecharse de Pérez materialmente porque las entrevistas siempre volvían a la cuestión de las posesiones del reo. Pérez, a quien le habría parecido que el lugarteniente y el teniente de prestamero tenían otros motivos que no suponían repartir justicia, disimuló lo más que pudo durante su primer interrogatorio. Explicó que era cristiano viejo de Madrid y que el lunes anterior había alquilado una mula del arriero Fernández para viajar a Bilbao en búsqueda de su hermano, Alonso, de quien su familia no sabía nada desde hacía tres años ${ }^{15}$. La noche anterior, contó, había dormido en Durango y tenía planes de marcharse para San Sebastián. Preguntado por lo que llevaba consigo, declaró que comenzó su jornada con mil reales y una cadena de oro que le colgaba del cuello. De los mil reales, aseveró, había gastado 200.

$\mathrm{Su}$ acompañante Francisco Fernández también tuvo que dar su relato. A Pérez, aseguró, le había alquilado el macho en que montaba. También dijo que era sevillano, hacía seis años que trabajaba como mozo de mulas y conoció a Pérez en el camino. Declaró que no sabía nada más, sólo sabía que su compañero de camino buscaba a su hermano en Vizcaya ${ }^{16}$.

Estas confesiones no convencieron a Zaldívar porque Sagasta estaba seguro de que Fernández y Pérez eran moriscos. Entonces, el mismo día a Pérez le obligó a que se explicase otra vez, ahora preguntando por qué pueblos había pasado entre Madrid y Bilbao. Pérez replicó que no se acordaba de los nombres

13. ARCV, Sala de Vizcaya, c. 4770-3, f. 1r.

14. Fuero nuevo de Vizcaya, Durango, España, 1976, 10.

15. ARCV, Sala de Vizcaya, c. 4770-3, ff. 3r-3v.

16. Ibídem, f. $4 \mathrm{v}$. 
de los lugares. Por segunda vez se declaró "vecino natural de la dicha villa de Madrid y cristiano viejo y limpio de raza de moros, moriscos y de los nuevamente convertidos" ${ }^{\prime 17}$. Sagasta y Zaldívar de nuevo revisaron la mula y la ropa de Pérez y, a su pesar, no encontraron nada ${ }^{18}$.

A estas alturas, es probable que Zaldívar y Sagasta se exasperasen. Sospechaban que Pérez, según sus apariencias, era morisco y ocultaba dinero (habían ya revisado su mula e indumentaria dos veces). Deseosos de al menos averiguar la descendencia morisca de su preso, iniciaron una probanza. Llamaron a varios vecinos del pueblo como testigos para decir si el forastero era cristiano viejo o morisco. Como nadie de Durango lo conocía, los testigos decían que no sabían nada de sus orígenes sino que les parecía un hombre bueno y de la pequeña nobleza ${ }^{19}$. Sin ninguna evidencia que contrariase que fuese cristiano viejo, lo soltaron, devolviéndole los 800 reales, su mula y sus otras pertenencias ${ }^{20}$.

Aunque a Pérez le parecía que podía continuar su viaje el mismo día que había estado en la cárcel pública de Durango, el 26 de enero fue devuelto de nuevo al mismo lugar. Su estrategia para defenderse la primera vez fue decir que era cristiano viejo. En esta ocasión decidió presentarse como menor de edad y, otra vez, es probable que eso también fuese mentira. Más tarde, apenas tres meses después, el conde de Salazar diría que "se registró ante mí Juan Pérez vecino de la ciudad de Toledo de edad de veinte y cinco años de buena estatura, blanco de rostro con señales de biruelas en el y un Rossa en la frente y una señal pequeña de herida Junto a la boca" ${ }^{21}$.

Menor de edad o no, fue obligado a confesar por tercera vez. Aunque Pérez sostuvo su argumento de tener pocos años, asumió su identidad de morisco granadino trasladado a Toledo. Afirmó que se marchaba de España por el bando del 2 de enero. El toledano también reveló que iba a comprar lana en Bilbao antes de que entrase en Francia para venderla en Venecia ${ }^{22}$. Además, explicó que había mentido diciendo que era cristiano viejo porque temía malos tratos: los moriscos (y con esta opinión estaremos de acuerdo) siempre eran objeto de abusos en el camino ${ }^{23}$. Por último compartió, en esta tercera confesión, su gran secreto: llevaba 20.600 reales escondidos en el cojín de la silla de su mula, con un anillo de oro, que iba a usar para comprar sus mercadurías antes de pasarse al extranjero ${ }^{24}$. El 27 de enero Zaldívar repitió el interrogatorio y Pérez

\footnotetext{
17. Ibídem, f. $7 \mathrm{v}$.

18. Idem.

19. Ibídem, f. $8 \mathrm{v}$.

20. Ibídem, f. 10r.

21. ARCV, Sala de Vizcaya, c. 4776-2, f. 2r.

22. ARCV, Sala de Vizcaya, c. 4770-3, ff. 10v-11r.

23. Ibídem, f. 11r.

24. Ibídem, ff. $11 \mathrm{v}-12 \mathrm{v}$.
} 
le dio las mismas respuestas ${ }^{25}$. El lugarteniente, entonces, le leyó el bando del 2 de enero, enfatizando el hecho de que se prohibía que los moriscos se llevasen dinero del país. Es curioso que Zaldívar también le leyese el apartado del bando que decía que los moriscos sí podían llevarse mercancías ${ }^{26}$. Al día siguiente entrevistó a Pérez de nuevo y el reo contestó, por cuarta vez, de la misma manera que en las dos ocasiones anteriores.

Antes de seguir narrando las complicaciones que se presentaron en este caso, nos parece oportuno señalar que las sospechas de Zaldívar de que Pérez trató de exportar monedas de España podían ser, aunque no sinceras, sí significantes a pesar de que resultó que él y sus cómplices trataron de beneficiarse económicamente de la situación. Para nosotros es llamativo que Pérez confesase que uno de sus destinos era Bilbao. Es evidente que Zaldívar sólo sospechó que el morisco quería pasar dinero a Francia porque Bilbao queda muy cerca de allí. Lo que sabemos (y Zaldívar quizás no) es que los moriscos en 1610 ya tenían costumbre de tratar de exportar sus bienes por la frontera con Francia con la ayuda de redes de mercado negro.

Zaldívar probablemente no supiese nada de cómo operaba por lo menos una de esas redes desde la frontera con Francia, porque las autoridades españolas no se percataron de esta actividad contrabandista internacional hasta 1620. El sistema funcionaba para auxiliar a los moriscos expulsados de esta manera: un judeoconverso portugués, llamado Diego Pereira, desde Bilbao enviaba hierro, acero, pecas y mosquetes a Berbería a cambio de ámbar y mercadurías, también prestaba los servicios de su red a los moriscos que querían vivir en el extranjero guardando su dinero y joyas. Sólo hacía falta, según aconsejaban los portugueses a los moriscos, venir a Bilbao antes de presentarse delante del conde de Salazar en Burgos. Los moriscos dejaban sus bienes en manos de los mercaderes extranjeros en Bilbao, se presentaban delante del conde de Salazar para comunicar su deseo de marcharse, declarar lo que llevaban consigo y después entraban a Francia, donde su dinero y joyas los esperaban, gracias al trabajo de exportación que maniobraban los cómplices de Pereira que, por supuesto, incluía cambiar el dinero de los moriscos por monedas de vellón para introducirlas en España ${ }^{27}$. Como Luis Bernabé Pons ha observado, los moriscos granadinos estaban especialmente interesados en estas redes de contactos: ya en años anteriores a los bandos de expulsión esta comunidad cohesionada comenzaba a establecerse en Túnez y a partir de 1610 los granadinos ayudaban a otros miembros de su comunidad para que se marchasen de España conservando su hacienda ${ }^{28}$.

25. Ibídem, 4770-3, f. 19v.

26. Ibídem, 4770-3, f. 20r.

27. J. CARRASCO VÁZQUEZ, «Contrabando, moneda y espionaje (el negocio del vellón: 1606-1620)», Hispania, 197, 1997, pp. 1081-1105.

28. L.F. BERNABÉ PONS, «Notas sobre la cohesión de la comunidad morisca más allá de su expulsión de España», Al-Qantara, XXIX, 2008, pp. 307-322. 
Si Juan Pérez no trataba de salvar su hacienda con el servicio de los judeoconversos portugueses con sus bases en Bilbao y Francia, posiblemente fuese él mismo contrabandista en el conjunto de contactos moriscos con bases establecidas en todo el Mediterráneo, un sistema en el que también estaban involucrados los judeoconversos portugueses y venecianos. En esta cadena mercantil ilícita se exportaban monedas y joyas de España a Francia para que pasasen por Irún y por fin a Venecia ${ }^{29}$. Esta posibilidad es especialmente atractiva porque Venecia figura en el testimonio de Pérez: dijo que quería usar el dinero para comprar lana en Bilbao con la esperanza de venderla en esa ciudadela italiana.

La gran suma de dinero que el morisco tenía escondida llegó a tener mucha importancia después de la interpelación del 28 de enero, cuando Pérez por primera vez acusó a Zaldívar y sus dos cómplices (Sagasta y el escribano de cámara Domingo de Massaga). Tras el interrogatorio el morisco gritó a Zaldívar declarando que el lugarteniente Sagasta y el escribano Domingo de Massaga encontraron los 20.600 reales en el cojín de su cabalgadura y los dividió entre sí, además de que tomaron unos ducados que tenía en una caja de mermelada ${ }^{30}$. Zaldívar se aprovechó de su autoridad respondiéndole que no podía hacer nada hasta que comprobase que era cristiano viejo ${ }^{31}$. Después, a Pérez lo desnudaron y lo devolvieron a la celda, negándole sus demandas de tomar escribanía para manifestar una denuncia ${ }^{32}$. Como las quejas de Pérez no le ayudaron a mejorar su situación de preso, la noche del 28 de enero él y su compañero Fernández se escaparon, hallando refugio en la iglesia de Mañaria.

El día 29, al enterarse de que sus “delincuentes” habían huido, Zaldívar formalmente les acusó de tratar de sacar dinero de España. Prosiguió con la probanza en la ausencia de los denunciados. Los testigos, además de declarar que Pérez recibió buenos tratos en la cárcel, confirmaron que Pérez buscaba un puerto seco para ir a Francia, que llevaba 20.600 reales y que les ofreció dinero por dar falso testimonio diciendo que era cristiano viejo ${ }^{33}$.

Aunque Pérez y Fernández ahora estaban protegidos en la iglesia de Mañaria, Zaldívar mandó sacarlos de su asilo. Entonces, el mismo día 29, Pérez "tiene pedida restitución a la iglesia de donde le sacaron estando en ella gozando de la inmunidad Eclesiástica" ${ }^{34}$. Aunque trataron de seguir con las pesquisas a sus presos, Pérez se negó a contestar más preguntas demandando ser devuel-

29. G. Wiegers, «Managing Disaster: Networks of the Moriscos During the Process of the Expulsion from the Iberian Peninsula Around 1609», Journal of Medieval Religious Cultures, 36.2, 2010, pp. 141-168.

30. ARCV, Sala de Vizcaya, c. 4712-1, pieza 1, f. 30r-30v.

31. Ibídem, f. 31r.

32. Ibídem, f. $5 \mathrm{v}$.

33. ARCV, Sala de Vizcaya, c. 4770-3, f. 37r-45r.

34. Ibídem, f. 60r. 
to a la iglesia ${ }^{35}$. Zaldívar, entonces, le acusó también de salir de su vecindad sin el permiso que los moriscos de origen granadino estaban obligados a obtener ${ }^{36}$.

Mientras Pérez y su compañero pasaban el 30 de enero en la cárcel de Durango, el vicario del lugar se enteraba de que Zaldívar había mandado que sacasen a Pérez de una iglesia, violando así sus derechos a la inmunidad eclesiástica. El 31, este señor, el bachiller Fauste Ochoa de Uribe, despachó una carta amenazando a Zaldívar con la excomunión si no devolvía a los moriscos a la iglesia tres horas después de que recibiese su orden ${ }^{37}$. El teniente no hizo caso a la misiva y el primero de febrero fue excomulgado ${ }^{38}$. Enseguida Martín de Sagasta dimitió de su puesto de teniente de prestamero y el nuevo, Juan de Mandiola, restauró a los moriscos a la iglesia de Mañaria y con eso Zaldívar fue absuelto ${ }^{39}$.

El lugarteniente y el nuevo prestamero esperaron tres días a que los moriscos saliesen de la iglesia ${ }^{40}$. En la ausencia de los acusados, el 4 de febrero, Zaldívar otra vez los halló culpables de llevar armas sin permiso, de tratar de sacar dinero de España y de quebrantar la cárcel ${ }^{41}$. Condenó a Pérez a galeras de por vida y pena de muerte si escapaba del remo eterno. A Fernández lo desterró de Durango por cuatro años con la amenaza de galeras si no cumplía ${ }^{42}$. Ambos tenían que pagar 10.000 maravedís a la cámara.

A partir de este momento la situación se volvió más complicada, involucrando a la Real Chancillería de Valladolid y al conde de Salazar: cuando Zaldívar condenó a Pérez y Fernández, éstos dos ya se habían ido para Valladolid en secreto. Efectivamente, el 6 de febrero Pérez y su procurador comparecieron delante de la Audiencia de la Real Chancillería de Valladolid, apelando la sentencia de Durango y denunciando a Zaldívar, Sagasta y Massaga de fraude ${ }^{43}$. Al oír las quejas de Pérez, la Audiencia mandó que se presentase delante de Bernardino de Velasco, el conde de Salazar, administrador de la expulsión general de los moriscos. El 14 de febrero estuvo delante de éste ${ }^{44}$.

La fecha exacta de la entrevista entre Bernardino de Velasco la sabemos gracias a la carta que el conde escribió el 7 de abril, en que confirmó que le daba licencia a Pérez para que recurriese la sentencia del proceso de Durango en que fue condenado a galeras y pleitease con Zaldívar, Massaga y Sagasta

\footnotetext{
35. Ibídem, f. $60 \mathrm{v}$.

36. Ibidem, f. 61r.

37. Ibidem, f. $72 \mathrm{v}$.

38. Ibídem, f. $73 \mathrm{v}$.

39. Ibidem, ff. $75 \mathrm{r}-76 \mathrm{v}$.

40. Ibídem, f. $76 \mathrm{v}$.

41. Ibídem, f. 78r.

42. Ibídem, f. $78 \mathrm{v}$.

43. ARCV, Sala de Vizcaya, c. 4712-1, f. 12r.

44. Ibídem, f. $14 \mathrm{r}$.
} 
para recuperar su dinero ${ }^{45}$. En la misma misiva el conde también aseguró que el mismo 14 de febrero mandó que su juez comisario, Eugenio Bonillo, viajase a Durango y comenzase un proceso para determinar el destino de los tres vizcaínos: el conde ya se fiaba de todo lo que Pérez le decía sobre su pérdida material y quería averiguar si era apropiado subastar los bienes de los vizcaínos a cambio del dinero robado ${ }^{46}$.

Bonillo llegó a Durango el 24 y comenzó su investigación para determinar lo que hacer en cuanto a los bienes de los oficiales de Vizcaya ${ }^{47}$. Mientras el procurador de Pérez lo representaba en la Audiencia vallisoletana, el morisco se quedaba unos días en Durango con Bonillo para demandar todo lo que los vizcaínos le habían hurtado; entonces, el juez comisario mandó que Zaldívar y compañía le devolviesen los bienes confiscados al morisco de Toledo ${ }^{48}$. Reconociendo que los vizcaínos acusados no estaban presentes (porque estaban en Valladolid por la apelación de Pérez), Bonillo visitaba las casas de Durango y revisaba los bienes de los tres hombres ${ }^{49}$. Al final de la búsqueda inicial (que tal vez durase unos días, el resumen no lleva fecha), Bonillo sospechó que los vizcaínos se habían llevado el dinero y, tal vez por esperar suficiente tiempo para que el dinero de Pérez apareciese, no comenzó a oír testigos hasta abril ${ }^{50}$. El 26 de febrero en Valladolid, durante las investigaciones preliminares de Bonillo, la audiencia de la Real Chancillería halló justicia a favor de Pérez: mandaron la restitución de los 20.600 al demandante morisco y le quitaron la sentencia de galeras dada en Durango. También, a Zaldívar, Sagasta y Massaga les absolvieron de las acusaciones de malos tratos ${ }^{51}$.

El morisco, sin embargo, no pudo escapar de los intereses reales hacia su dinero porque el mismo día que la Audiencia decidió el caso, el fiscal real Pedro de Corral apeló la restitución del dinero a Pérez, arguyendo que pertenecía al rey ${ }^{52}$. Las justicias enseguida arrestaron a Zaldívar y Sagasta en Madrid, en medio de la búsqueda de Pérez. Inmediatamente protestaron haber sido tomados presos por ser vizcaínos, citando la Ley XIX del fuero de Vizcaya ${ }^{53}$. El

45. Ibídem, f. $1 \mathrm{r}$.

46. Idem.

47. ARCV, Sala de Vizcaya, 4712-1, pieza 3, f. 1r.

48. Ibídem, ff. $4 \mathrm{r}-5 \mathrm{v}$.

49. Ibídem, ff. 6r-11r.

50. Ibídem, f. 104r.

51. ARCV, Sala de Vizcaya, 4712, pieza 1, f. 1 r.

52. Ibídem, f. $1 \mathrm{v}$.

53. ARCV, Sala de Vizcaya, 4770-3, ff. 80r-80v. Según la Ley XVI del fuero de Vizcaya, los vizcaínos gozaban de su hidalguía fuera de Vizcaya y, asimismo, la Ley XIX prohibía que cualquier juez fuera de Vizcaya, menos el juez mayor de Vizcaya, tuviese jurisdicción sobre ellos: Fuero пиеvo de Vizcaya, 12-13. 
16 de marzo hubo un proceso para determinar si los dos presos eran vizcaínos originarios. Seis testigos afirmaron que lo eran ${ }^{54}$.

Poco importaba la hidalguía vizcaína: el 19 del mismo mes seguían en la cárcel de la Chancillería. También Zaldívar y Sagasta se defendieron diciendo que no trataron de huir con el dinero y que aquél había sido juez sobre Pérez en Durango antes de que el conde de Salazar recibiese su comisión ${ }^{55}$. Repetidas veces la Chancillería dictaminó que los vizcaínos depositasen el dinero robado y los vizcaínos siempre pidieron que se les diese la libertad, los deseos de ambas partes quedaron incumplidos. Se observó que Pérez depositó todo lo que tenía mientras que Zaldívar y sus dos cómplices entregaron "tan solamente trescientos y cincuenta y ocho escudos" ${ }^{\prime \prime}$.

En abril el juez comisario Bonillo, desde Durango, se puso en contacto con el juez mayor de Vizcaya, Antonio de Mezqueta, pidiéndole que mantuviese presos a los vizcaínos ${ }^{57}$. Durante todo este mes Bonillo ejecutó los bienes de Zaldívar, Sagasta y Massaga ${ }^{58}$. El conde de Salazar también le mandó la carta que ya hemos mencionado al juez mayor de Vizcaya, dando fe de que Pérez apareció delante de él el 14 de febrero ${ }^{59}$. El conde arguyó que el morisco no quiso salir de España llevándose el dinero, sino que quería comprar mercadurías, sosteniendo así la defensa de Pérez que se apoyaba también en el bando del 2 de enero ${ }^{60}$.

Entre el 3 y el 6 de abril, en Durango, el juez comisario Bonillo presidió el proceso para decidir si se subastaban los bienes de los vizcaínos. Los testigos estaban encantados de su oportunidad de calumniar a los acusados: según las confesiones, Zaldívar, Sagasta y Massaga solían aprovecharse de los viajeros que pasaban por el pueblo y esto mismo es lo que hicieron al morisco toledano ${ }^{61}$. Todos los testigos también se acordaron de cómo sacaron a Pérez de la iglesia sin ninguna jurisdicción sobre é ${ }^{62}$. Un testigo particular, llamado Felipe de Bereinagen, para caracterizar a los tres acusados como salteadores de camino más que administradores de justicia, recordó otro caso semejante al del robo y maltrato que le hicieron a Pérez: aparentemente Zaldívar, Domingo y Massaga "eran íntimos y grandes amigos" que solían asaltar a los viajeros: una vez secuestraron a un estudiante, desnudándolo y apropiándose de sus posesiones ${ }^{63}$. En total,
54. Ibídem, f. 3r.
55. Ibídem, f. $7 \mathrm{r}$.
56. Ibídem, f. 9r.
57. Ibidem, f. $15 \mathrm{r}$.
58. Ibidem, f. 22r.
59. Ibídem, f. $27 \mathrm{r}$.
60. Ibídem, f. 31r.
61. ARCV, Sala de Vizcaya, 4712-1, pieza 2, ff. 105r-105v.
62. Idem.
63. Ibídem, ff. 121r-122r. 
14 testigos de Durango confirmaron que Zaldívar, Sagasta y Massaga eran corruptos, asaltaban a la gente en el camino real y que se llevaron 20.600 reales a Madrid, los cuales se los habían hurtado a Pérez. También uno, Martín de Mallagaray, confirmó que Massaga usaba su oficio de escribano para falsificar papeles $^{64}$. Para cuestionar más la autoridad de Zaldívar, casi todos los testigos dijeron que había tenido dos mancebas. Hay un pleito en la Real Chancillería de Valladolid que lo confirma: en agosto de 1594, varios testigos afirmaron que Zaldívar había mantenido a sus mancebas María de Uribe y Marina Zurriaga durante nueve años, "las dos al presente preñadas del susodicho" ${ }^{65}$. Aunque no haya prueba que demuestre si Bonillo revisaba los pleitos para confirmar si los testigos decían la verdad, nosotros por lo menos podemos confirmar que la opinión de los testigos era sincera. Parece claro que Zaldívar, Sagasta y Massaga asaltaban a los forasteros que pasaban por Durango y robaron a Pérez.

Para Bonillo, entonces, no quedaba ninguna duda acerca de los delitos del lugarteniente, el teniente prestamero y el escribano de Durango. Juzgó que el fiscal real debía ver las probanzas y determinar una sentencia. Éste contestó: "el fiscal real es interesado particularmente en el dicho pleito y Vuestra Merced [Bonillo] ha de condenar a los susodichos y a cada uno en graves penas corporales y pecuniarias" ${ }^{\prime 66}$. También demandó castigos para Pérez porque le parecía que el morisco trataba de burlar el bando del 2 de enero ${ }^{67}$. El 2 de septiembre, entonces, acusaron a Zaldívar de esconder sus posesiones de las autoridades reales ${ }^{68}$. Aunque la Audiencia en Valladolid otra vez mandó que pagase los 20.600 reales el juez mayor de Vizcaya revocó la sentencia ${ }^{69}$.

Bonillo, al recibir la respuesta del fiscal real, decidió su caso el 6 de abril: Zaldívar, Sagasta y Massaga debían pagarle 20.600 reales a Pérez. También les dio una sentencia de galeras a Zaldívar y Sagasta mientras castigó a Massaga con el destierro de Vizcaya y la revocación de sus privilegios como escriba$\mathrm{no}^{70}$. En mayo se subastaron todas las posesiones de los vizcaínos para recuperar el dinero perdido ${ }^{71}$. En junio Zaldívar apeló la subasta que Bonillo había montado el mes anterior.

Durante el año de la apelación de Zaldívar, el 23 de septiembre la Real Chancillería revocó la sentencia de Mezqueta porque se halló, sin ninguna duda, que no era obligatorio que Pérez registrase sus 20.600 reales si viajaba entre Bil-

\footnotetext{
64. Ibídem, ff. 161v-162r.

65. ARCV, Sala de Vizcaya, 1323-3, f. 4r.

66. ARCV, Sala de Vizcaya, 4712-1, pieza 2, f. 190r.

67. Idem.

68. Ibídem, f. 16v.

69. Ibídem, f. 29r.

70. Ibídem, f. 195r.

71. ARCV, Sala de Vizcaya, 2797-3, f. 8r.
} 
bao y San Sebastián, esta última ciudad siendo un destino que Pérez añadió en su apelación que no figuró en los procesos en Durango ${ }^{72}$. Además, el morisco aportó documentos constatando que su padre, Jerónimo Pérez, gozaba de todos los derechos de los cristianos viejos, los cuales incluían llevar armas, porque el padre de Jerónimo, Juan de Mendoza, se había convertido en cristiano antes de las conversiones generales de Granada (1500-1501) ${ }^{73}$. Para acompañar la evidencia documental, tres testigos confirmaron que Juan Pérez podía llevar armas, que era mercader y solía comprar mercancías en San Sebastián ${ }^{74}$.

Al principio de 1611 los vizcaínos y Pérez siguieron pleiteando en Valladolid hasta que, el 26 de febrero, la Real Audiencia de Valladolid dio su sentencia en la apelación que Pérez había presentado el año anterior: fallaron que Pérez debía recibir sus 20.600 reales, los tres vizcaínos tenían que ser absueltos de cualquier acusación de malos tratos al morisco y revocaron la sentencia dada en Durango sobre Pérez ${ }^{75}$. El mismo día el fiscal del rey apeló la sentencia en cuanto a la restitución del dinero a Pérez y, desde luego, el 27 de mayo de 1611 la Chancillería revocó su sentencia para que los 20.600 reales se destinasen al rey ${ }^{76}$.

Del morisco Juan Pérez de Toledo no se sabe más: la última sentencia dada en Valladolid sobre su apelación cierran estos legajos que dan una idea de una etapa tan difícil de su vida. Parece que, según los detalles que esta aportación documental provee, puede ser la última etapa de la vida en España de Juan Pérez de Toledo, que también podía haber sido mercader de lana, corredor de monedas o contrabandista. Si es un ejemplo de una expulsión autoadministrada, su experiencia ante los tribunales españoles sin duda fue un caso extremo, pero también ejemplifica los peligros a los que los moriscos afrontaron al comenzar el viaje para Francia durante el primer año de la expulsión general.

Pero, ¿qué habría sido de él? Se sabe que, antes de la expulsión, muchos moriscos granadinos de familias privilegiadas cruzaron la frontera con Francia para, al final, establecerse en Túnez, ciudad musulmana que había llevado siglos acomodando a los musulmanes españoles. Bernabé Pons ha observado que se necesita más investigación sobre estas familias, en particular porque le parece importante saber por qué abandonaron Granada antes de la guerra de las Alpujarras, especialmente porque advierte el importante papel que habrían desempeñado en las redes de contactos moriscos que fueron tan importantes durante la expulsión ${ }^{77}$. De hecho, desde la Edad Media había una estructura de

72. ARCV, Sala de Vizcaya, 4770-3, ff. 4r-4v.

73. ARCV, Sala de Vizcaya, 4776-2, f. 6 r.

74. ARCV, Sala de Vizcaya, 4712-1, pieza 2, ff. 39r-46r.

75. ARCV, Sala de Vizcaya, 4712-1, pieza 1, f. 196r.

76. Ibídem, f. 131r.

77. L. BERNABÉ PONS, «Notas sobre la cohesión de la comunidad morisca más allá de su expulsión de España», Al-Qantara, XXIX, 2008, pp. 307-332. 
acogida basada en relaciones personales entre los moriscos tunecinos y los que vivían en otras partes del Mediterráneo; entonces, aunque esa red de contactos se extendió alrededor del Mediterráneo en parte gracias al mercantilismo, puede caracterizarse la inserción de los moriscos españoles en la sociedad tunecina como algo limitada por la naturaleza personal de ese sistema de acogi$\mathrm{da}^{78}$. Si seguimos las observaciones de Bernabé Pons, parecería que ayudaba mucho ser de una familia granadina para tener la oportunidad de incorporarse en la sociedad morisca de Túnez.

No se puede descartar, entonces, la posibilidad de que Pérez quisiese llegar a Túnez después de pasar la frontera con Francia gracias a plausibles contactos granadinos en Túnez. Por casualidad, vivían unos mercaderes de lana moriscos que se llamaban Juan Pérez en Túnez, aunque el origen de ninguno es conocido. Estos individuos aparecen en la documentación de los archivos del consulado de Francia en Túnez, estudiada por Míkel de Epalza. Uno, Juan Pérez, envió lana de Sussa a Livorno en 1616; posiblemente este mismo individuo fue un "prestamista notorio entre los moriscos de la primera generación" que realizó varias transacciones; otro, alias Mahamad Jayyar o Moro Galam, fue socio del famoso Luis Zapata, alcalde de la comunidad morisca en Túnez, que fue destinado a la Inquisición de Palermo cuando fue cautivado durante una excursión naval hacia Sicilia ${ }^{79}$. No hemos de olvidar que el escritor morisco toledano Ibrahim Taybilí, exiliado en Túnez, también se llamaba Juan Pérez en España. ¿Era nuestro Pérez uno de estos personajes?

Si el destino de Pérez no fue Francia ni Túnez, tal vez fuese Marruecos. Pastrana, según Mercedes García-Arenal y Fernando Rodríguez Mediano, se convirtió en el nuevo Albaicín de Granada después de la segunda guerra de las Alpujarras: muchos moriscos granadinos fueron a morar allí durante la conversión $^{80}$. También han encontrado un enlace entre Pastrana y Toledo, ciudad en que Pérez vivía: la Inquisición de Toledo halló libros árabes de Pastrana en Toledo en 1631, lo cual sugiere que los moriscos granadinos de Toledo y Pastrana tenían varios contactos de intercambio ${ }^{81}$. A su vez, los moriscos de Pastrana (y, por extensión, de Toledo) probablemente tuviesen contactos con Marruecos, dado que el morisco Diego Aguacil/Muhammad Alguazir, escritor de tratados anticristianos de Pastrana, se estableció en Marrakech y tenía relaciones con la nobleza marroquî ${ }^{82}$.

78. M. de EPAlZA, «Estructuras de acogida de los moriscos emigrantes de España en el Mágreb (Siglos XIII al XVIII)», Alternativas: Cuadernos de Trabajo Social, 4, 1996, pp. 35-58.

79. M. de EpAlZA, «Moriscos y andalusíes en Túnez durante el siglo XVII», Al-Qantara, XXXIV, 1969, pp. 247-327.

80. M. García-Arenal y F. Rodríguez Mediano, Un oriente español, Madrid, 2010, p. 281.

81. Ibidem, p. 284.

82. Ibídem, p. 299. 
En fin, aunque no podemos ahora mismo precisar exactamente quién fue nuestro morisco granadino de Toledo, tenemos un pleito de riquísima información que nos ofrece una viñeta que representaría una de las experiencias moriscas de la expulsión. Queda claro que las autoridades de Vizcaya estaban vigilando los caminos cuando se publicó la pragmática de expulsión de 1610 para interrumpir cualquier irregularidad cometida por los moriscos que se iban para Francia. También, y más importante, podemos ver que la percepción social del morisco como dispuesto a esconder riquezas invitaba a los agentes de la justicia a beneficiarse económicamente de ellos cuando viajaban. El caso de Pérez, entonces, puede ser visto como ejemplar de una de las dificultades con las que los moriscos se enfrentaron a la hora de irse de España: tuvieron que salvar lo que podían de sus posesiones y defenderlas de todo el mundo, incluso de los oficiales corruptos. También hemos dejado algunas sugerencias de quién podía haber sido de este personaje. Ojalá ayude este estudio en la reconstrucción de las redes de moriscos en el Mediterráneo para encontrar la respuesta.

\section{APÉNDICE: ¿IBRAHIM TAYBILÍ?}

¿Podía ser este morisco el autor que más tarde se llamaría Ibrahim Taybilí? Relegamos la cuestión a un apéndice porque solamente podemos ofrecer las coincidencias entre nuestro Juan Pérez y el autor hispanotunecino sin hacer declaraciones definitivas. De todos modos, Jaime Asín supuso que el escritor tenía orígenes murcianos, sugiriendo una procedencia de Taibilla para sus ancestros, un pueblo ya olvidado en la Edad Media ${ }^{83}$. Fuere el que fuere el origen de sus antepasados, Taybilí era un Juan Pérez morisco de Toledo como el Pérez de nuestros pleitos que hemos expuesto ${ }^{84}$. También comparte otra característica con el Juan Pérez de los procesos: dominaba magistralmente el castellano. Pérez pudo engañar a los vecinos de Durango, Vizcaya, para que no pudiesen decir con certeza si era morisco o cristiano viejo. También Taybilí y Pérez eran mercaderes: Pérez llevaba 20.600 reales y vivían prestamistas llamados Juan Pérez en Túnez. Podemos decir que los dos participaron en redes financieras. ¿Cuántos moriscos llamados Juan Pérez, vecinos de Toledo, habrían sido mercaderes y exportado monedas? Desafortunadamente, como el nombre Juan Pérez es común, por ahora hemos de presentar la identificación de este morisco con Taybilí como una hipótesis. Sin embargo, los dos personajes comparten unos rasgos significantes y, si nos fijamos en las circunstancias de Taybilí, no es difícil imaginar que podía ser el morisco detenido en Durango.

83. J. Oliver ASÍN, «El Quijote de 1604», Boletín de la Real Academia Española, 28, 1948, pp. 89-126, 109.

84. I. TAYBILÍ, Contradicción de los catorce artículos de la fe cristiana, en L.F. BERNABÉ PONS, El cántico islámico del morisco Taybili, Zaragoza, 1988, p. 155. 
Taybilí, exiliado en Túnez, escribió la Contradicción de los catorce artículos de la fe cristiana en 1628. Este cántico islámico, escrito en castellano, participa en una tradición literaria peculiar para Túnez. Ahí moraban tantos moriscos deseosos de asimilarse a la cultura tunecina que era necesario que se les comunicase en castellano "realidades semánticas árabes" que "marcarían toda la producción literaria de los moriscos de Túnez" ${ }^{\prime 5}$. El poema sirvió de instrucción a un público morisco que había perdido el uso del árabe y quiso profundizar en la doctrina musulmana que les fue prohibida en España. La Contradicción, entonces, es como otros textos de su género: invalida los fundamentos de la fe cristiana en su ataque a la Santa Trinidad, argumenta que Cristo no fue hijo de Dios, desmiente que María fuese virgen y se burla de los sacramentos ${ }^{86}$. El autor mismo explica que su Contradicción es una forma poética del manuscrito Apología contra la ley cristiana de Diego Alguacil/ Muhammad Alguazir, un texto que se supone que su autor escribió en Pastrana antes de que se marchase para Marrakech ${ }^{87}$. Alguazir, por su conocimiento profundo de la doctrina cristiana y el castellano, fue seleccionado para escribir su polémica para un público cristiano y, aunque hasta cartas diplomáticas de embajadores marroquíes se dirigen a estados cristianos prestando pasajes de su texto, la polémica de Alguazir evidentemente interesaba mucho a los moriscos en la diáspora ${ }^{88}$.

Desde luego, la puesta en poesía de la prosa de Alguazir es una muestra del sentir el catolicismo como erróneo, una inversión de las acusaciones de herejía que los moriscos sufrieron en España. Así Taybilí convierte la cruel expulsión de los moriscos en una salvación de las almas de los musulmanes españoles:

“Felipho, Rey de España, se dispone pensando descubrir su fortaleza, y es que por ynstrumento de Dios le pone de su ynfalible y inmortal çerteça.

Hordena Dios que el bando se pregone, que salgan los moriscos con presteça, y biene a sser camino esta salida para que en libertad passen la vida" ${ }^{89}$.

Explica también que los moriscos, durante la expulsión, "[d]ejan sus casas, muebles, muy contentos", ignorando (u omitiendo) la laboriosa y peligrosa jor-

85. Ibídem, p. 49.

86. L. CARdaillaC, Moriscos y cristianos: Un enfrentamiento polémico (1492-1640), México, 1977, pp. 217-219.

87. I. Taybilí, op. cit.; M. García-Arenal y F. Rodríguez Mediano, Un oriente español, p. 299.

88. G. WIEGERS, «The andalusi heritage in the Maghrib: The polemical work of Muhammad Alguazir (FL. 1610)», en O. Zwartjes, G.J. VAN GELder, E. De Moor (eds.), Poetry, Politics, and Polemics: Cultural Transfer between the Iberian Peninsula and North Africa, Orientations, Amsterdam, 1997, Orientations 4, pp. 107-132.

89. I. TAYBiLí, op. cit., p. 157. 
nada que sus correligionarios experimentaron para tener esa libertad ${ }^{90}$. Tomando en cuenta la experiencia de Juan Pérez, quien quizá se marchase de España antes de que la expulsión fuese obligatoria para él, podemos imaginar por qué Taybilí escribió esos versos. El proyecto de ambas personas -Pérez el viajero asaltado por justicias vizcaínas y, en teoría, Taybilí el escritor anticristiano- fue buscar la libertad oponiéndose a los abusos y la codicia de los cristianos.

El autor, aunque se representa en su cántico como enemigo de la doctrina cristiana, posiblemente no odiase la lengua y literatura españolas. En primer lugar, escribe en castellano, un idioma profundamente suyo que no ha olvidado. Segundo, en el prólogo a su obra cuenta una anécdota acerca de su vida en España: un día en que pasó por una librería de Alcalá de Henares. Después de comprar seis libros, su compañero le comenta:

"Por Dios, señor Juan Pérez, que ssi iba a decir verdad, yo no e bisto cossa de gusto ni e entendido nada en lo que e leydo. Si Vm. conprara al Caballero de Febo, Amadís de Gaula, Palmerín de Oliba, Don Belianís de Greçia y otros semejantes que tienen honra y probecho, y ver aquel balor de aquellos caballeros y aquellas haçañas tan famosas" ${ }^{\prime \prime 1}$.

Un estudiante en la librería se ríe del acompañante del autor y, enseguida, también todos los clientes que se encontraban en la librería en aquel momento. La anécdota, fijada en el comentario imprudente de un lector ingenuo y la risa que lo sigue, sirve para reflejar los gustos de un vulgo español -de los que su público lector expulsado puede acordarse- a los que tengan una experiencia literaria mucho más amplia que la de un lector de poca educación. Siguiendo la convención, Taybilí explica que su libro no es para un lector al que le gusten exclusivamente los libros de caballerías, sino para alguien más discreto, conocedor de la literatura de "buen gusto". Queda claro, entonces, que Taybilí era conocedor de la literatura española de su época y es probable que soliese leerla (incluso la del género caballeresco). También tenía una familiaridad con la convención de escribir prólogos en español, en los que el autor se dirige a un lector "discreto" contrastándolo con el "vulgo".

Otro texto polémicamente atribuido a Taybilí es el manuscrito S-2 de la Colección Gayangos de la Biblioteca de la Real Academia de la Historia de Madrid; sin embargo, no se puede aceptar que Taybilí fuese el autor de este texto aunque éste y el del S-2 tienen mucho en común ${ }^{92}$. El manuscrito es una miscelánea que refleja los gustos literarios del llamado "refugiado de Túnez", autor anónimo que podría ser cualquiera de los varios escritores con quienes los estudiosos lo han identificado. Entre las instrucciones religiosas que ofrece a los

90. Idem.

91. Ibídem, p. 153.

92. L. LÓPEZ-BARALT, «Estudio preliminar», Tratado de los dos caminos por un morisco refugiado en Túnez, ed. de Á. Galmés de Fuentes, Madrid, 2005, p. 65. 
moriscos de Túnez se encuentran novelas ejemplares. Como el texto expresa un odio total a los españoles, Luce López-Baralt ha notado una crisis de identidad del autor, a la vez que se siente identificado con la literatura y cultura españolas y marginado por ellas ${ }^{93}$. Estos mismos choques culturales se encuentran en las Contradicciones de Taybilí, puesto que el autor se acuerda de la anécdota en la librería alcalaína, con ello retrata la literatura española en el prólogo a su desprestigio textual de la religión de España.

Podemos imaginar, entonces, a un Juan Pérez, igual al caso de Ibrahim Taybilí, atrapado entre dos mundos durante su último año en España: enfrentándose con la ironía de ser expulsado mientras se encontraba detenido para que no cumpliese con los reales decretos y su propia preferencia. Según los testigos que se personaron en sus procesos, tenía un aire de nobleza y cultura ${ }^{94}$. Disimuló, al principio con éxito, su identidad morisca porque hablaba el castellano tan bien como las justicias que lo procesaron y lo sentenciaron. No es difícil, entonces, imaginarlo como Taybilí o el "refugiado de Túnez", aprovechándose de su oportunidad de vivir en el exilio y educando a sus correligionarios en la fe musulmana mientras que por escrito atacaba a los que le habían maltratado.

En este momento, entonces, no se puede declarar definitivamente que nuestro morisco toledano era el autor que en Túnez se llamaría Ibrahim Taybilí. Sin embargo, no se puede tampoco ahora descartar esta posibilidad. Ambos personajes coinciden en unas características lo suficiente como para justificar más investigación sobre el asunto: eran mercaderes llamados Juan Pérez; vivieron en Toledo; pasaron por Francia; recibieron una buena formación en la lengua castellana y es fácil imaginar a nuestro morisco detenido en Vizcaya como un individuo de dos culturas como lo era Taybilí, profundamente español y árabe.

\section{RESUMEN}

Este ensayo es el fruto de una investigación que principalmente se realizó en el Archivo de la Real Chancillería de Valladolid. Se basa en una larga serie de expedientes encontrados en la sección de la Sala de Vizcaya del mismo archivo. Aquí se explica un caso poco esperado de un morisco de origen granadino cuya familia había sido recolocada en Toledo después del segundo levantamiento de las Alpujarras (1568-1572). El morisco, llamado Juan Pérez, decidió administrar su propia expulsión de España siguiendo el edicto del 2 de enero de 1610 o transportaba dinero para una red de mercado negro. Pasando por Vizcaya, tratando de llegar a Francia, las justicias de Durango lo detuvieron, intentando quedarse con el dinero que Pérez llevaba escondido en su cabalgadura. Además de de-

93. L. LópeZ-BARAlt, La literatura secreta de los últimos musulmanes de España, Barcelona, 2009, p. 445.

94. ARCV, Sala de Vizcaya, c. 4712-1, ff. 5r-12r. 
mostrar que existieron representantes de la justicia que quisieron aprovecharse de la situación vulnerable de los moriscos expulsados, este trabajo también ofrece hipótesis acerca de la identidad y el destino final de este individuo.

Palabras clave: expulsión, moriscos, Granada, Toledo, Vizcaya.

\section{ABSTRACT}

This essay is the result of research that was principally performed in the Archivo de la Real Chancillería de Valladolid. It is based on a long series of records found in the Sala de Vizcaya section of that archive. Here is explained a rare case about a Morisco of Granadan origin whose family was relocated to Toledo after the second Alpujarras uprising (1568-1572). The Morisco, named Juan Pérez, decided to either administer his own expulsion following the January 21610 edict or was transporting money for an underground trade network. Passing through Biscay, trying to arrive to France, the authorities of Durango detained him, trying to keep Pérez's money for themselves, which he had hidden in his saddle. In addition to demonstrating that there existed legal authorities that tried to take advantage of the vulnerable situation of the expelled Moriscos, this work also offers hypotheses about this individual's identity and final destination.

Key words: expulsion, Moriscos, Granada, Toledo, Vizcaya. 